Article Type: Research Paper

\title{
How does the Public Attitude Towards Advertising Controversial Products \& Advertising Ethics?
}

\author{
Salihah Khairawati* and Mu'tashim Billah Murtadlo
}

\begin{abstract}
The aim of this paper is to determine attitudes towards the advertistment of certain controversial products and the reasons for being offensive among Indonessian peoples in Yogyakarta. This research method was qualitative, achieved by analyzing the responses of informans by depth interview method. The results indicated that peoples refused advertistment openly broadcasted of certain controversial products, such contraception, underwear, alcohol, and others. For cigarette, there were two responses most of them received cigarette advertisment and the other disagree. Advertisment should obeyying advertisment ethics and goverment should regulating advertisment for controversial products, especially when the advertisment contradictory with religions, values and social norms in muslims countries. The implication of this research for those involved in marketing, it is important that they are aware of possible cultural and religion sensitivities when entering a market or undertaking a standardized mass-media campaign across a region. Limitation of this reserach were few informans, further research can be suggested to conduct future study by taking more respondent and using quantitative method.
\end{abstract}

Keywords: Attitude; Advertisment; Controversial Products.

\section{Introduction}

The importance of advertising ethics ware concerned for many scholar, including researchers and marketing practitioners Tuncay, Zayer and Coleman (2015). Research on advertising ethics in many countries has been done by earlier researchers such as (Boeul \& Darvean, 2017; Azizah, 2016; Moser, Stevens, and Loudon, 2016). Shabbir, Maalouf, Griessmair, Colmekcioglu, and Akhtar (2018) exemines an exploratory perception of advertising. Kamalul, Ismail, and Mohammad (2016) conducts a correlation study of reliability with advertising. Turnbull and Boulanouar (2016) standardizes advertising ethics. Similarly, the study of the advertising of the controversial products has been examined in several countries whose population are Muslimmajority (Farah, 2015; Madni, Hamid, \& Rashid, 2016). Waller, Fam, \& Erdogan (2005) examines factors that encourage rejection of controversial product advertisements. Waller and Fam (2000) 
examines the controversial product advertising practices in Malaysia. Fam, Waller,Ong, \& Yang, (2008); Mohammad, Farzana, Nomahaza, Nazimah, (2015) conducted a controversial product ads review with religious beliefs. Fereidouni (2008) in his research report examines a cultural stance on advertising controversial products among the case study women in Penang. The study of advertisements was conducted by Waller et al., (2005) by reviewing cross-cultural studies of controversial product advertisements.

Social research according to Mulyadi (2011) is a research on the phenomenon where researchers become instruments. In qualitative approaches researchers utilize themselves as an instrument, as the human instrument is more supple to capture the various realities and interactions that occur. According to Rahmawati (2007) interviews in qualitative research allowed researchers to uncover social symptoms in the field by exerting all its function to reveal the hidden data through spoken language, body language, and expressions of the world and the environment of the informant. Accprding to that reason, this study used a different approach than previous studies, this research using a qualitative methods with interview techniques. In addition, researchers have expanded the research problem, which is trying to uncover how people's attitudes toward advertising controversial products and how people's attitudes towards advertising ethics.

Departing from the context of Yogyakarta people who still pay attention to the cultural values that are derived from religion allegedly influence his attitude towards something. Yogyakarta citizen were known as societies that still holds cultural values. Although as a student implicates the gathering of heterogeneous cultures, the community still upholds the cultural values that have been adopted. The inclusion of Islam to Indonesia until the level of state administration in Mataram Sultanate has a lot of influence in the formation of cultural values.

The purpose of this research is to get an overview of how people's attitudes toward advertising controversial products as well as how the ethical position of advertising in organizing the advertisements served in the media.

The study divided into five sections, the first is an introduction that discusses the research background, research objectives, and formulation of research issues. Second, discusses the theory and study of literature. The third section is about research methodologies, such as the type of research, methods used, data collection and data analysis methods. The fourth section is a section that contains discussion and research results. In the fifth part discusses the implications of research, conclusions, research limitations as well as advice for advanced research.

\section{Literature Review and Hypotheses Development}

According to Azwar (1998), attitudes can be defined to be a response. The response will only arise when the individual is faced with a symptom that requires an individual reaction. The response form is referred to as evaluative response. Evaluative response is based on the evaluation process within an individual who will provide a value conclusion 
in good or bad form, positive or negative, pleasant or objection able, like or dislike that then forms as potential reaction to an object of attitude. Attitudes can also be interpreted as a through evaluation that allows people to respond in an advantageous or unprofitable way consistently with regard to objects or alternatives given (Purnama, 1999). Attitudes are always related to a particular object, thus the attitude object in this study is advertising. The attitude towards the advertisement is the overall evaluation of the consumer on an advertisement, both in its media and the copy of its ads (Ciptono, 1999).

According to Azwar (1998) the factors influencing the formation of attitudes among others are personal experience, the influence of others that are considered important, cultural influences, mass media, educational institutions and religious institutions as well as emotional factors.

AMA (American Marketing Associaton) defines advertising as all forms of payment to present and promote non-personal ideas, goods or services by a clear sponsor (Ciptono, 1999). Advertising is aimed at creating a demand for products in the minds of consumers by affecting consumers ' feelings to feel they need them. The function of advertising is to evangelize audiences about the ins and outs of products (informative), affecting audiences to buy (persuading), and refreshing information that audiences have received (reminding) as well as creating a pleasant atmosphere as the audience receives the information (Ciptono, 1999:247).

Controversial product is interpreted as a product, service or concept that can create a precarious condition while in contact with customs morality, morality is even able to cause hate reaction, rejection if called or demonstrated openly (Waller \& Fam, 2000). According to Waller et al., (2005) products included in the controversial catagories such goods, services and concepts. As for those that are inserted into the category of controversial goods are alcohol, contraceptives, cigarettes, underwear, food banned, while those that are included in the category of services are the services that are haraam such as prositution, gambling. Controversial product advertising is a product advertisement that ethically raises its ability if openly publicized (Akhter, Abassi, \& Umar, 2011).

Research on controversial product advertisements has been conducted by Akhter, et.al (2011) in Pakistan. The results of his research found that public apity of $70 \%$ of controversial product advertisements was influenced by religious, perceptional gender. Rice, Gillian and Mossawi (2002) in their research on the acceptance of advertisements in the Middle East found that the public tends to receive advertisements that correspond to the religious values he has adopted. Waller and Fam (2000) in their research on advertising in Malaysia found that images, language or messages in advertisements contrary to religious values were reasons to be restricted.

Research conducted by Maya and Samad (2015) on controversial product advertising to a number of Lebanese citizens found that there was a difference in perception between Sunni Muslims and Shi'a Muslims on controversial product advertisements. Shia Muslims are harder to resist the advertising of sex products, gender than Sunni Muslims. 
Tariq and Khan (2017) in a survey conducted on 250 college students in the northern region of India stated that there is a discrepancy between Muslim Indians with Hindu Indians on advertising, which the difference of attitude are influenced by religion and degree of diversity. This research confirms the importance of marketers understanding things that can cause religious sentiment from consumers and avoids those things so that the ads can be received by both consumers. Shafiq, Haque and Jan (2017) conducted a study of aspects of belief in Islamic advertising in Malaysia. In their studies to a number of students and members of universities in Malaysia that confidence in Islamic advertising is very different from the belief in advertising generally.

From the study done by Cader (2015) revealed that there is a relationship between religiousity, advertising and rejection. For advertising agencies it is very important to understand how religiousity can affect rejection, affect the attitude advertising and improve the effectiveness of advertising.

Ads serve to provide information about the ins and outs of products. The advantage of the advertisement is that consumer will know the existence of a product and the function of the product. Instead the ads is also able to give negative impact on the basic characteristics of the ads, which is persuasive, frequency and exposure. The into style of advertising for example, will encourage consumers to consumptive that leads to materialistic. Recognizing the positive and negative impacts on advertisements, an ethic is required among advertising actors. Ethics are principles of fundamental morality that will direct human behavior. As one moral order, ethics is strongly influenced by culture. Every culture has values that are local and inter-local and even global. Cultural values will affect the ethical norms that are formed.

Advertising ethics is the normative provisions relating to the profession and advertising efforts that have been agreed to be respected, obeyed, and enforced by advertising actors so that it always matches the values embraced by the community. Ethical issues in advertising are the truth of an advertisement and public manipulation according to Satyanugraha in Azizah (2016).

\section{Research Method}

This research uses qualitative research approaches. Qualitative research is a research method based on the philosophy of postpositivism or enterpretif, used to examine on the condition of natural objects, where researchers as a key instrument, data collection technology is done triangulation (combined), data analysis is inductive or qualitative and the results of qualitative research emphasize the meaning of generalization (Sugiyono, 2018). The format of this research is a qualitative descriptive format, as stated by Leksono (2013) that the qualitative diskriptif format is more appropriate if used in research related to problems requiring study deep. In-depth studies can be a matter of consumer behaviour, media effect issues on the viewer's view of media impressions, public policy implementation in society and other similar (Atmadi and Widati, 2013). 
This research uses three informant with certain consideration that is the indigenous people of Yogyakarta Islamic religion aged 17 to 65 years often intentionally or accidentally watched ad impressions of controversial products in various media. This consideration is done in the hope that the informant can provide adequate and required information by the researcher. The method of data collection used in this study by conducting an in-depth interview (indepth interview) with some informant to obtain direct response. The selection of this informant is based on the understanding that the informant is a person who is already considered an adult, so as to think and understand the question well and be able to communicate well. Semi-structured interviews were chosen in this study. This interview begins with the issue covered in the interview guidelines, but the interview guidelines ensure researchers can gather the same type of data from participants (Rahmawati, 2007). Analysis used is the analysis of filling system. The analysis of filling system will divide the question instruments into categories according to their kind. This analysis is used to classify the results of research data, both in the form of bullet points and the explanation of interviews and observations to certain groups (Kriyantono, 2008:100). Test the validity of data in research using triangulation test with qualitative method. The data analysis technique is conducted with three flow of adapt atan that must be followed the three are interconnected. The three grooves consist of: data reduction, data presentation, and verification or withdrawal of conclusions. The researcher develops a variable of questions on factors forming attitudes toward advertising derived from the opinion of Azwar (1998) namely:

Table 1 Informant question variables

\begin{tabular}{cl} 
No & \multicolumn{1}{c}{ Question Variables } \\
\hline 1 & $\begin{array}{l}\text { Individual experience } \\
\text { Influence of others: culture, mass media, educational institutions, religious } \\
\text { institutions }\end{array}$ \\
3 & Emotional factors \\
4 & Attitudes towards controversial product ads \\
5 & Attitudes towards controversial products \\
6 & Attitudes towards advertising ethics \\
7 & Attitudes towards advertising regulation \\
\hline
\end{tabular}

\section{Result and Discussion}

Based on the results of in-depth interviews with the informant can be described as follows:

\section{Factors influencing the attitude of informant}

The attitudes are essentially influenced by factors from inside and outside the individual themselves. The role of outside parties is large enough to influence one's attitude. Outside parties come from reference groups, families, relationships. While a factor of the individual self can be a personal experience, a personal principle. Fators-factors that 
affecting the informant attitude towards the advertisement of controversial products as the interview results below:

Informant 1: Mass media such as television, radio and newspaper affect my attitude towards advertising controversial products. I watched the ads of controversial products that were shown naturally, inadvertent because they often appeared on television.

Informant 2: Television for me remains the main affect my attitude towards advertising controversial products. I do not always intend or deliberately witnessed the advertisement

Informant 3: Sometimes friends and family also influence my attitude towards advertising controversial products. I watched the ads of the contract products accidentally, because they were shown in many media and easily watched

The informant witnessed intentionally or unintentionally the impression of controversial product advertisements that served in various mass media blatantly over along period of time so that some controversial product types were considered as regular. Informant witnessed the advertisement of intensive and continuous controversial products in the mass media affecting the informant stance on controversial products. Researchers have argued that activities undertaken continuously become a habit and are able to shape people's attitudes toward things. The informant attitude can be formed also from social interaction, association with friends, relatives, family and community can influence the attitude of informant to the advertisement of controversial products. Through opinion, the view of the other party provides its own suggestion for the informant to behave towards something they felt.

The role of a religious institution or educational institution can essentially affect the informant attitude of controversial product advertisements, such. through a fatwa Ulama, or a teacher or educator's appeal. In relation to this, as the interview results with some of the following informant is derived the idea that the role of the formal institution above is not much influential.

Informant 1: The religious or school institution is not too influential to me

Informant 2: I am not tied to a religious institution or educational institution so that my attitude towards advertising is controversial products as it as

Informant 3: For me a religious institution or educational institution does not have much influence, because my attitude is built on my own principle

The role of a religious institution is not strong enough to influence the attitudes of the informant of controversial product advertisements, because of the intensity of the religious institutions in establishing non-intensive communications such as ad impressions. Similarly, the institution and experience is not strong enough to affect the 
attitude of informant. Controversial ads products today are widely served in a variety of advertising media.

Many television stations, advertising media, print media are utilized by marketers to inform the product to prospective buyers and influence consumer behaviour. According to some of the controversial product ads informants that often appear many are:

Infroman 1: Cigarette ads are the ads that appear most frequently on television, but the advertising of the ads in rarely appears

Informant 2: The ads that appear most on the advertising medium of both televisions, outdoor ads are cigarettes, alcohol ads are almost rarely found

Informant 3: Cigarette ads are the most and most easily found in the media, alcohol ads are seldom shown in ads

Advertising the most controversial products served in the advertising media according to the informant based on the order of the most up to a few are: cigarette advertising, stimulant drug advertising, contraceptive advertising. As for the advertising of underwear products and alcoholic beverages only served in limited media such as magazines therefore only a little informant knows the ads served through the magazine. While according to answers to informant services and other controversial products such as pork, prostitution services, gambling sites are not served through general advertising media so that the informant does not know the advertisement of such products and services.

\section{The informant response to the advertising of controversial products}

Advertisers engage in promotional efforts to attract prospective buyers, gain the candidate's attention by creating ads. Controversial products are often shown in the advertising media to receive diverse responses from some informant:

Informant 1: It is natural to serve, so that the company can attract consumers, so that the products are sold, it is necessary to have ad impressions in the ad media and it is considered common because the environment is so

Informant 2: Unnatural or taboo by assuming that to attract consumers to the products sold, it is necessary to offer a more specialized method of bidding, not open advertising.

Infomant 3: Reasonable if the product is not vulgar, but if the product is vulgar then taboo if openly advertised strong drugs, contraceptives, and liquor products and so on

Company and advertiser efforts to gain the attention, response and response of potential buyers in marketing activities are reasonable. As a business activity it is acceptable, but it is necessary to be regulated so as to not be vulgar in the advertising of controversial products. 


\section{Attitudes towards controversial products}

The product basically offers a pinch of benefits for consumers. Products have the value offered to consumers. On the basis of benefits and value consumers make a purchase. In this regard, some respondents argued:

Informant 1: Products such as cigarettes, contraceptives, underwear, although called controversial but beneficial to the consumer, except gambling, liquor, prostitution inappropriate for the east (especially Javanese Muslim)

Informant 2: Products such as contraceptives, underwear though taboo but I use it. But for products such as pork, alcoholic drinks and gambling clubs are not beneficial especially for Muslims

Informant 3: There is no problem with such products as cigarettes, a range in the cause I use, I still feel cigarettes beneficial to me. But ads that others are inappropriate with Javanese norms

Informan considers controversial products to be beneficial because it is the average of respondents using such products as cigarettes, contasepsy and underwear. Cigarette products although in some research are included in the category of controversial products, but cigarettes promoted by the culture of Indonesian society so that cigarettes are not considered a controversial product. Cigarettes are still considered by a large informant not a controversial product and are very familiar with people's lives. Anticigarette movements, anti-tobacco, and even government campaigns for non-smoking areas, anti-smoking education do not affect the informant attitude of the cigarette itself. These findings corroborate Pribadi's research (2013) that the influence of smoking risk ads on the attitudes, perception, value and interest buying of cigarette consumers in Banda Aceh said that the risk advertising of smoking was addressed neutrally by respondents, even though they know the dangers of smoking, but the interest of smoking remains high.

As for other controversial products such as stimulant drugs, contraceptives, there is a taboo feeling of the informant because this issue according to the informant is not feasible to be publicly available. While other controversial products such as liquor, pork, prostitution, gambling means, obtained negative responses from the informant because it is considered not good and not in accordance with the cultural norms of Yogyakarta (Java) and religious teachings Especially Islam.

\section{Attitudes Towards Advertising Ethics}

The application of ethics in business needs to be a concern for business people, as well as advertising ethics arranged so that no parties are harmed in business and advertising practices within the community. The opinion of the informant regarding the implementation of advertising ethics are following : 


\section{Khairawati \& Murtadlo}

How does the Public Attitude Towards Advertising Controversial Products \& Advertising Ethics?

Informant 1: The current advertising ethic is good enough to be obeyed by the advertiser and so far it has been going well

Informant 2: Advertising ethics has not been optimally obeyed by advertisers.

Informant 3: Advertising ethics has not been executed properly ads must be ethical, polite, reasonable and not vulgar

According to the informant with an advertiser's conversion to advertising ethics will have a good impact on the life of society.

\section{Advertisment Controversial Product, culture, norms and religions}

Culture, norms and religions are the factors that come from outside the individual. As a factor from outside, culture, norms and religions become guidelines in one's behavior and attitudes. Culture, norms and religion in Javanese especially Yogyakarta is still a guideline in daily activities. Based on the interview, a number of informants have been obtained the following answers:

Informant 1: Culture, norms and religions do not affect the perception of something

Informant 2: The culture, norms and religions that I have an influence affect my perception of something

Informant 3: My perception of something is being perceived by culture, norms and religion

We recommend that advertising adapt itself to norms or cultures including religion. What is considered taboo by customs or cultural norms and religions, it should be avoided. Culture or cultural norms derived from the sublime values that are passed down in the community in this context is a Yogyakarta culture that is strong with Javanese customs that are still closed enough for private things.

The informant states that religious factors are a major factor affecting their perception of controversial product advertising, other informants state that religion does not affect their perception of controversial product advertisements. As for the explanation of the informant above the values derived from religious teachings in this context still play an important role in influencing perception, although in the interpretation of the religious teachings of the informant emphasizes on contextual non-textual. According to the informant, if the advertisement will be received well by the audience (community). The advertiser and the company need to understand the culture and values that are held by the society both customary and religious, so as not to cause rejection.

The informant's opinion illustrates the character of the informant that still holds religious and cultural values. This opinion reaffirmed the research done by (Akhter, 2011; Waller 
and Fam, 2000; Chachula, 2009) that the controversial advertising of the products that do not heed the ethics and the prevailing norms in the community will be granted rejection.

\section{How should the ads regulation be?}

The ads regulation are setted to protect the public society, business actors and other parties from the detrimental matters committed by the parties. However, public knowledge of ads regulation needs to be examined, as the respondent answers about it:

Informant 1: I do not understand the content of ads regulation, but I think the law or regulation should be used to regulate advertising practices

Informant 2: I have never read ads regulation, so I don't know exactly how ads regulation in Indonesia

Informant 3: Although I do not understand the content of ads regulation, it is recommended that the rules be applied and obeyed by advertisers

All informants do not understand or know the content of regulation or laws regarding advertising. The limitation of literacy on ads regulation or laws is an obstacle for them to criticize further. Even so they agreed there should be a setting about advertising. According to the informant, governments, competent institutions and communities should be involved in monitoring the delivery of controversial product advertisements, in order that there is no negative impact on society. The laws governing advertising must be understood and adhered to by advertiser companies and marketers. According to informers, such as broadcast hours, clothing and appearance of models or artists that advertise and the content of advertising messages and the information submitted in ads must be arranged.

Law enforcement in violation of consumer protection laws about advertising should be undertaken. It is also asserted by Amrani (2016) under the society and law enforcement should be involved in advertising surveillance, because in their research found the fact that low community participation is still in supervising cases of violations Advertising Law No 8 year 1999 article 17 paragraph 1 concerning information content. This is because people are reluctant to deal with legal institutions, and are resigned to unlawful advertising cases.

Given that, the importance of community involvement is to actively monitor and report if there are things that do not comply with the ethics and the prevailing rules. Researchers assessed the need for education about community critical awareness and attitudes about the importance of advertising ethics and the role of various parties to supervise advertising practices in advertising media. Of course, this needs to get serious attention from the government, the Indonesian Consumer Protection Foundation (YLKI) and the community in the future does not pose any problems from the advertisements that are publicly displayed and vulgar. 


\section{Conclusion}

From the results and research discussion can be described conclusions Mass Media is a factor that affects public attitudes towards advertising controversial products, the impact of ads impressions and exposure to mass media ads is able to influence the attitude of society. Cigarette product ads are the most widely aired contovertial products on open advertising media, following stimulant drug ads and contraceptives. Where a liquor and underwear advertising is aired on closed and limited media such as magazines, and advertisements of contoverable products and services such as pork, prosititution, and gambling are ads that have never served through the media. Controversial product that does not acquire rejection and is considered not taboo is a cigarette, while for other products is considered taboo. It is necessary to affirmations the rules or laws of advertising, so that the advertisements served do not cause negative problems and impacts on the community.

This research is a qualitative study with a limited number of informers, expected that future research can use more respondents with heterogeneous respondents such as ethnic, religious, age and gender with quantitative methods. This research providing an overview of the attitude of the informant that is a resident of Yogyakarta and is known as an open and religious society influenced by cultural factors and religious. As an evaluation of advertising strategy policy for business actors to be more cautious in advertising so as not to cause negative attitudes from the community. This research can also be an input for the government to evaluate the laws or rules regarding the advertising ethics that are applicable.

\section{References}

Akhter, W, Abassi, A. S. \& Umar, S. (2011). Ethical Issues Advertising in Pakistan: An Islamic Perspective. World Applied Sciences Journal, 13(3), 444-452. Retrieved from https://www.academia.edu/19124515/Ethical Issues in Advertising in Pakistan A n Islamic Perspective

Amrani, H. (2016). Perilaku Menyimpang Praktik Bisnis Periklanan dalam Perspektif Hukum Pidana dan Penegakan Hukumnya, Jurnal Hukum Ius Quia Iustum Faculty of Law, Universitas Islam Indonesia, 23(4), 495-511. https://doi.org/10.20885/iustum.vol23.iss4.art4

Arham, M. (2010). Islamic perspectives on marketing. Journal of Islamic Marketing, 1(2), 149164, . https://doi.org/10.1108/17590831011055888

Atmadi. G., \& Widati. S. R .W. (2013). Strategi Pemilihan Media Komunikasi LPPOM MUI Dalam Sosialisasi \& Promosi Produk Halal d Indonesia. Jurnal Al Az̧̧ar Indonesia Seri Panata Sosial, 2(2), 87-97. https://jurnal.uai.ac.id/index.php/SPS/article/view/150

Azizah, M. (2016). Etika Perilaku Periklanan dalam Bisnis Islam. JESI Jumal Ekonomi Syariah Indonesia), 3(1), 37-48, http://dx.doi.org/10.21927/jesi.2013.3(1).37-48

Azwar, S. (1998). Sikap Manusia Teori dan Pengukurannya. Yogyakara: Pustaka Pelajar.

Bari, A., \& Rana, Z. A. (2011). Advertisement and Islam: A Muslim World Perspective. Australian Journal of Business and Management Research, 1(6), 152-157. 
https://www.academia.edu/5939531/ADVERTISEMENT_and_ISLAM_A_MUSLI M WORLD PERSPECTIVE

Boeuf , B., \& Darveau, J. (2017). An Ethical Perspective on Necro-Advertising: The Moderating Effect of Brand Equity. Journal of Business Ethics. 4. Retrieved from https://www.springerprofessional.de/en/an-ethical-perspective-on-necro-advertisingthe-moderating-effec $/ 12213598$

Cader, A. A. (2015). Islamic challenges to advertising: a Saudi Arabian perspective. Journal of Islamic Marketing. 6(2), 166-187. https://doi.org/10.1108/JIMA-03-2014-0028

Chachula, G., Kurheski, H., Lubas A., Malachouski, K. \& Martinovski, B. (2009). The Influence of Selected Aspects of Islam on Advertising Efforts. The 16 th NIC Conference on Intercultural Communication. School of Business and Informatics University of Borus Sweden.

Ciptono, F. (1999). Strategi Pemasaran. Andi: Yogyakarta

Waller, D. S. (2004). What factors make controversial advertising offensive?: A preliminary study. In ANZC A04 Conference (pp. 1-10). Sydney: University of Technology.

El-Bassiouny, N. M., Wilson, J. A., \& Esmat, S. (2017). An Islamic Macromarketing Perspective on Sustainability. Journal of Islamic Marketing, 8(2), 187-203. https://doi.org/10.1108/JIMA-09-2015-0069

Waller, D. S., \& Fam, K. S. (2000). Advertising of controversial products: The Malaysian experience. Alcohol, 10, 1-706.

Fam, K. S., Waller, D. S., Ong, F. S., \& Yang, Z. (2008). Controversial product advertising in China: perceptions of three generational cohorts. Journal of Consumer Behaviour: An International Research Review, 7(6), 461-469. https://doi.org/10.1002/cb.264

Fereidouni, H. G. (2008). Cultural Attitude Towards Print Media of Controversial Products Among Female Consumers in Penang. Thesis Report. Malaysia

Kamalul, A., S., Ismail, I., \& Mohammad, S, K. A. (2016). Religiuosity Moderates the Relationship Between Ego-defensive Function and Attitude Towards Advertising. Journal of Islamic Marketing, 7(1), 15-36. https://doi.org/10.1108/JIMA-11-2014-0074

Keenan, K, \& Shoreh, B (2000). How advertising is covered in the Egyptian press: a longitudinal examination of content. International Journal of advertising. 19(2), 245-258, https://doi.org/10.1080/02650487.2000.11104797

Kriyantono, R. (2008). Teknik Praktis Riset. Kencana Prenada Media Grup.

Ketelaar, P. E., Konig, R., Smit, E. G., \& Thorbjørnsen, H. (2015). In ads we trust. Religiousness as a Predictor of Advertising Trustworthiness and Avoidance. Journal of Consumer Marketing, 32(3), 190-198. https:// doi.org/10.1108/JCM-09-2014-1149

Leksono, S. (2013). Penelitian Kualiatif Ilmu Ekonomi dari Metode ke Metode, Rajawali Grafindo, Jakarta.

Madni, A. R., Hamid, N. A., \& Rashid, S. M. (2016). Influence of Controversial Advertisement on Consumer Behavior. The Journal of Commerce. 8(1-2), 14-24.

Retrieved from http://joc.hcc.edu.pk/articlepdf/joc201607009-pp14-24.pdf

Maya, F, F., \& El Samad, L. (2015). Controversial product advertisements in Lebanon: A study of Sunni-Shi'a sectarian disparities and similarities. Joumal of Islamic Marketing, 6(1), 22-43, https://doi.org/10.1108/JIMA-02-2014-0013

Mohammad, J, Farzana, Q, Nomahaza, M. , Nazimah, H. (2015). Religious Faith, Addictive Products, and Their Advertisement: A Qualitative Inquiry. International Journal of Innovation and Business Strategy. 3(July).

Moser, H.R., Stevens, R., \& Loudon, D.(2016). An empirical analysis of ethical and professional issues in physicians' advertising: A comparative cross-sectional study. Health Marketing Quarterly. 33, NO. 3, 255-273. https://doi.org/10.1080/07359683.2016.1199225 
Mulyadi, M. (2011). Penelitian Kuantitatif dan Kualitatif Serta Pemikiran Dasar Menggabungkannya. Jurnal Studi Komunikasi dan Media 15(1) (Januari - Juni 2011), 127138. Retrieved from https://www.neliti.com/publications/134513/penelitiankuantitatif-dan-kualitatif-serta-pemikiran-dasar-menggabungkannya

Pribadi, J. (2013). Pengaruh Iklan Resiko Merokok Terhadap Sikap, Persepsi, Nilai dan Minat Membeli Konsumen Rokok di Banda Aceh. Jurnal Visioner \& Strategis, 2(1), 39-48. Retrieved from https://rp2u.unsyiah.ac.id/index.php/welcome/prosesDownload/7166/4

Purnama, L. (1999). Strategic Marketing Plan. Gramedia Pustaka Utama: Jakarta

Rachmawati, I. N. (2007). Pengumpulan Data dalam Penelitian Kualitatif: Wawancara, Jurnal Keperawatan Indonesia. 11(1), 35-40, http://dx.doi.org/10.7454/iki.v11i1.184

Rice, G., \& Mossawi, A. M. (2002). The Implication of Islam in Advertising Messages: The Middle Eastern Context. Journal of Euromarketing. 11(3), 71-96. https://doi.org/10.1300/j037v11n03 05

Shabbir, H. A., Maalouf, H., Griessmair, M., Colmekcioglu, N., \& Akhtar, P. (2018). Exploring perceptions of Advertising Ethics: An Informant-Derived Approach. Journal of Business Ethics, 159(3), 727-744. https://doi.org/10.1007/s10551-018-3784-7

Shafiq, A., Haque, A., Abdullah, K., \& Jan, M. T. (2017). Beliefs About Islamic Advertising: an Exploratory Study in Malaysia. Journal of Islamic Marketing, 8(3), 409-429, https://doi.org/10.1108/JIMA-02-2015-0018

Sugiyono. (2018). Metodologi Penelitian Manajemen. Pernerbit Alvabeta: Yogyakarta

Tariq,.M \& Khan,. M. (2017). Offensive advertising: a religion based Indian study. Journal of Islamic Marketing, 8(4), 656-668. https://doi.org/10.1108/JIMA-07-2015-0051

Tuncay, Zayer, L., \& Coleman, C. A. (2015). Advertising Professionals' Prceptions of the Impact of Gender Portrayals on Men and Women: A Question of Ethics?. Journal of Advertising, 44(3), 1-12, https://doi.org/10.1080/00913367.2014.975878

Turnbull, L.H., \& Boulanouar, A.W. (2016). The advertising standardisation debate revisited: implications of Islamic ethics on standardisation/localisation of advertising in Middle East Islamic States. Journal of Islamic Marketing, 7(1), 2-14. https://doi.org/10.1108/JIMA-11-2014-0072

Waller, D. S., Fam, K. S., \& Erdogan, B. (2005). Advertising of controversial products: a cross-cultural study. Journal of Consumer Marketing, 22(1),6-13. https://doi.org/10.1108/07363760510576509 